\title{
DWDM Networks When Using Raman Configurations with DCF Fibers
}

Geovanny Andrés Muñoz Castro / geovannymuoz@hotmail.com

Universidad del Cauca, Popayán-Colombia

ABSTRACT In this paper, the basic theoretical foundations regarding a DWDM [Dense Wavelength Division Multiplexing] network when using Raman configurations with DCF [Dispersion Compensation Fiber] are studied, through the revision of: linear effects, such as noise, loss, chromatic dispersion and PMD [Polarization Mode Dispersion]; and nonlinear effects, such as Self-Phase Modulation [SPM], Cross-Phase Modulation [XPM] and Four-Wave Mixing [FWM], compared to Optical Monitoring Parameters [OPM].

KEYWORDS DGF; DWDM; linear effects; nonlinear effects; Raman.

Redes DWDM al usar configuraciones Raman con fibras DCF

RESUMEN En el presente artículo se abordan los fundamentos teóricos básicos respecto de una red DWDM [Multiplexación Densa por División de Longitud de Onda] al usar configuraciones Raman con Fibras Compensadoras de Dispersión [DCF], mediante el estudio de: efectos lineales, como ruido, pérdidas, dispersión cromática y Dispersión por Modo de Polarización [PMD]; y efectos no lineales, como Modulación de Auto-Fase [SPM], Modulación de Fase Cruzada [XPM] y Mezcla de Cuarta Onda, frente a los Parámetros de Monitoreo Óptico [OPM].

PALABRAS CLAVE DCF; DWDM; efectos lineales; efectos no lineales; Raman.
Redes DWDM usando configurações Raman com fibras DCF

RESUMO Neste artigo são apresentados os fundamentos teóricos básicos a respeito de uma rede DWDM [Multiplexação Densa por Divisão de Comprimento de Onda] usando fibras de configuração Raman com Fibras Compensadoras de Dispersão [DCF] através do estudo de: efeitos lineares, tais como o ruído, perdas, dispersão cromática e Dispersão por Modo de Polarização por [PMD]; e efeitos não lineares tais como Auto Modulação de Fase [SPM], Modulação de Fase Cruzada [XPM] e Mistura de Quatro Ondas [FWM], em comparação com a Monitorização Óptica do Desempenho [OPM].

PALAVRAS-CHAVE DCF; DWDM; efeitos lineares; efeitos não lineares; Raman. 


\section{Introduction}

At present, data transport networks must be able to offer high levels of bandwidth due to the appearance of numerous applications such as video conferencing, growing internet traffic, real-time operations, high-speed services, etc. The constant growth of this demand has brought existing technologies to their limits; a situation that leads to require new concepts and innovations that allow the implementation of more robust networks, with greater capacity and higher transmission speeds. These needs that have arisen as a result of technological development have made optical fiber an attractive and highly projected medium to support the resources demanded by services of users, in terms of capacity and scope (García, 2011).

To increase the information transmission capacity, optical fiber employs Wavelength Division Multiplexing [WDM] techniques, which reduce network costs; however, such systems have limitations when used over long distances and at higher speeds, and are subject to optical degradations which generate undesired modifications in the signal. Dense Wavelength Division Multiplexing [DWDM] transmission systems represent an alternative to achieve transmissions over longer distances; the system in question is characterized mainly by providing a spacing between smaller wavelengths, increasing its transport capacity (Rec. ITU-T G.694.1-2012) and requiring, at the same time, the incorporation of new technologies and mechanisms, in order to minimize the incidence of linear and nonlinear effects on system performance.

Considering that Raman distribution amplifiers are a promising technology, by reducing the power of the input signal, without sacrificing the Optical Signal to Noise Ratio [OSNR] -the performance parameter that measures how much it degrades the optical signal that is transported within the system - after the transmission (Liu, 2002), using the Stimulated Raman Scattering [SRS] as the gaining mechanism of the amplifier (Rocco et al., 2009), and the Dispersion Compensation Fiber [DCF], allow to counteract the degradations generated by the chromatic dispersion thanks to the contribution of its properties, such as the negative dispersion index, attenuation and figure of merit, among others (Hoyos \& Vélez, 2013). Having said that, this article focuses on performing an analysis in DWDM networks when using Raman configurations with DCF fibers; for this, it is initially necessary to review basic theoretical fundamentals, bibliographic revision and works related to the subject in reference.

\section{Introducción}

En la actualidad, las redes de transporte de datos deben ser capaces de ofrecer elevados niveles de ancho de banda, debido a la aparición de numerosas aplicaciones, tales como: videoconferencia, creciente tráfico de internet, operaciones en tiempo real, servicios de alta velocidad, etc. El constante crecimiento de dicha demanda ha llevado las tecnologías existentes a sus límites; situación que lleva a requerir nuevos conceptos e innovaciones que permitan implementar redes más robustas, de mayor capacidad y más altas velocidades de trasmisión. Estas necesidades, surgidas como consecuencia del desarrollo tecnológico, han hecho de la fibra óptica un medio atractivo y de gran proyección para soportar los recursos demandados por los servicios de los usuarios, en términos de capacidad y alcance (García, 2011).

Para incrementar la capacidad de envío de información, una fibra óptica emplea técnicas de Multiplexación por División de Longitud de Onda, [WDM, Wavelength División Multiplexing], las cuales reducen los costos de la red; sin embargo, tales sistemas presentan limitaciones al emplearse en largas distancias y a mayores velocidades, y se encuentran expuestos a degradaciones ópticas que generan modificaciones no deseadas en la señal. Los sistemas de transmisión de Multiplexación Densa por División de Longitud de Onda [DWDM, Dense Wavelength División Multiplexing] representan una alternativa para alcanzar transmisiones a distancias mayores; el sistema en mención se caracteriza, principalmente, por brindar un espaciamiento entre longitudes de onda menor, aumentando su capacidad de transporte (Rec. ITU-T G.694.1-2012) y exigiendo, a la par, la incorporación de nuevas tecnologías y mecanismos, con el fin de minimizar la incidencia de los efectos lineales y no lineales sobre el desempeño del sistema.

Considerando que los amplificadores de distribución Raman son una tecnología prometedora, al reducir la potencia de la señal de entrada, sin sacrificar la Relación Señal Óptica a Ruido [OSNR, Optical Signal to Noise Ratio] -el parámetro de desempeño que mide qué tanto se degrada la señal óptica que es transportada dentro del sistemadespués de la transmisión (Liu, 2002), usar el efecto de dispersión Raman [SRS, Stimulated Raman Scattering] como mecanismo de ganancia del amplificador (Rocco et al., 2009), y las Fibras Compensadoras de Dispersión [DCF, Dispersion Compensation Fiber], permiten contrarrestar las degradaciones generadas por la dispersión cromática, gracias a la contribución de sus propiedades, tales como el índice de dispersión negativo, atenuación y figura de mérito, entre otras (Hoyos \& Vélez, 2013). Dicho esto, el presente artículo se centra en realizar un análisis en redes DWDM al usar configuraciones Raman con fibras DCF; para ello, inicialmente se retoman fundamentos teóricos básicos, revisión bibliográfica y trabajos relacionados con el tema en mención. 


\section{Consideraciones generales, referentes a WDM y DWDM}

WDM es una técnica de multiplexación para redes ópticas que permite multiplicar la capacidad de cada enlace al transmitir información de manera simultánea en una única fibra, para lo cual utiliza diferentes longitudes de onda, y logra así, optimizar el ancho de banda de la fibra y mayores tasas de transmisión. No obstante, una de las debilidades de este sistema es, principalmente, que sus canales no se encuentran estrechamente unidos en el dominio de la frecuencia, lo cual reduce la eficiencia en el medio de transmisión; adicionalmente, pueden presentarse dificultades para responder a diferentes degradaciones ópticas, tales como los efectos lineales y no lineales, los cuales se convierten en un limitante de la distancia del enlace y velocidad del sistema (Alvarado, 2009).

Por otra parte, debido a la evolución y oferta comercial de servicios informáticos, tales como videoconferencias, aplicaciones multimedia y telemedicina, entre otros, la DWDM proporciona una alternativa para aumentar el ancho de banda, ya que permite acomodar en una única fibra alrededor de un centenar de longitudes de onda, sin interferencia mutua; cada longitud de onda representa un canal óptico, sobre el cual se transporta un servicio. Las funciones de DWDM son múltiples, entre ellas: amplificar todas las longitudes de onda sin tener que convertir a señales eléctricas, tener independencia entre protocolos y capacidades, y transportar señales con diferentes velocidades; pese a ello, una de las principales características de DWDM es que puede llegar a enviar 32/40/64/80/96 canales virtuales multiplexados en una sola fibra óptica, con tendencia a aumentar por las diversas técnicas modernas que usan los proveedores (Melendez, 2013). Actualmente se pueden conseguir hasta 320 canales ópticos trasportando cualquier formato de transmisión, así es posible, utilizar diferentes longitudes de onda para enviar información analógica o digital (Sembroiz, 2013).

Los sistemas DWDM exigen una precisión de longitud de onda y rendimiento de filtrado superior a los sistemas WDM convencionales; esto se debe a que una pequeña desviación en el centro de la longitud de la onda de uno de los láseres puede distorsionar la señal del canal adyacente, de ese modo, la estabilidad de las lambdas o canales es de suma importancia (Ferrin, 2014).

Aunque DWDM se ha convertido en una técnica innovadora, eficaz y determinante para el transporte de información en sistemas ópticos, se deben tener en cuenta ciertos condicionantes: en primer lugar, es una tecnología que se encuentra en un punto intermedio de su desarrollo y es muy dependiente de las características de las fibras; en segundo lugar, se requieren componentes ópticos de gran calidad, como láseres con control de temperatura y sistemas de refrigeración, multiplexores y demultiplexores más desarrollados, que implican un aumento en el costo total de la red a

\section{General considerations, regar- ding WDM and DWDM}

WDM is a multiplexing technique for optical networks that allows multiplying the capacity of each link by transmitting information simultaneously in a single fiber, using different wavelengths, and in this way it manages to optimize the fiber bandwidth and higher transmission rates. However, one of the weaknesses of this system is that its channels are not closely linked in the frequency domain, which reduces the efficiency in the transmission medium; additionally, there may be difficulties in responding to different optical degradations, such as linear and nonlinear effects, which become a limiting of the link distance and system speed (Alvarado, 2009).

On the other hand, due to the evolution and commercial offer of computer services, such as videoconferences, multimedia applications and telemedicine, among others, the DWDM provides an alternative to increase the bandwidth, as it allows to adjust in a single fiber around a hundred of wavelengths, without mutual interference; each wavelength represents an optical channel, over which a service is transported. The functions of DWDM are multiple, including: amplifying all wavelengths without having to convert to electrical signals, having independence between protocols and capacities, and transporting signals with different speeds; in spite of that, one of the main features of DWDM is that it can send 32/40/64/80/96 multiplexed virtual channels on a single optical fiber, with a tendency to increase thanks to several modern techniques used by suppliers (Meléndez, 2013). At present, up to 320 optical channels can be achieved transporting any transmission format, so it is possible to use different wavelengths to send analog or digital information (Sembroiz, 2013).

DWDM systems require higher wavelength accuracy and filter throughput than conventional WDM systems; this is because a small deviation in the center of the wavelength of one of the lasers can distort the signal of the adjacent channel, thus, the stability of the lambdas or channels is of utmost importance (Ferrín, 2014).

Although DWDM has become an innovative, effective and determinant technique for the transport of information in optical systems, certain conditions must be taken into account: first of all, it is a technology that is at a midpoint of its development and is very dependent on the characteristics of the fibers; in second place, it is required high-quality optical components such as temperature-controlled lasers 
and cooling systems, more developed multiplexers and demultiplexers, which imply an increase in the total cost of the network to be installed (García, 2006). Finally, it is essential to mention that the fundamental difference between WDM and DWDM is the spacing between channels; in DWDM they are closer, therefore it has more capacity and makes use of a larger spectrum margin (García, 2006).

\section{Stimulated Raman scattering or SRS}

The origin of the Raman effect occurs when a high-intensity monochromatic light beam has an impact on the vibrations of the molecules and atoms of the material that forms an optical fiber; these vibrations characteristic of the material medium are called optical phonons. The result of the interaction causes that part of the energy is going to be absorbed by the medium and is going to be presented like a phonon that remains within the system; the rest of the energy leaves, generally, as a new photon of lower energy (less frequency and consequently, greater wavelength) than the incident photon; while the resulting photon is called Stokes, it can travel in the same direction of the incident beam (co-propagation) or in the opposite direction (counter-propagation). On the contrary, if the energy is higher (higher frequency) the anti-Stokes dispersion occurs (Sembroiz, 2013; Álvarez, Hernández, \& Quiroz, 2007; Hernández, 2011). The representation of the SRS process, in terms of electronic levels, can be seen in Figure 1.

Figure 1 shows that a photon with energy Wp (orange signal) is absorbed by the medium and makes a transition from the ground state to a virtual state of excited energy; after some time, part of that energy is transferred and the rest gives rise to a new energy photon Ws (red signal). If the final state of the transferred energy is located at a higher level than the initial state, the photon emission occurs at a lower frequency (lon- instalar (García, 2006). Finalmente, resulta imprescindible mencionar que la diferencia fundamental entre WDM y DWDM es el espaciamiento entre canales, en DWDM son más cerrados, por lo tanto, tiene más capacidad y hace uso de un mayor margen del espectro (García, 2006).

\section{Efecto de dispersión Raman o SRS}

El origen del efecto Raman se presenta cuando un haz de luz monocromático de alta intensidad incide sobre las vibraciones que tienen las moléculas y los átomos del material que conforma una fibra óptica; estas vibraciones, características del medio material, reciben el nombre de fonones ópticos. El resultado de la interacción, provoca que parte de la energía va a quedar absorbida por el medio y se va a presentar como un fonón que queda dentro del sistema; el resto de la energía sale, generalmente, como un nuevo fotón de menor energía (menor frecuencia y por ende, mayor longitud de onda) que la que presenta el fotón incidente; en tanto, al fotón resultante se lo llama Stokes, éste puede viajar en el mismo sentido del haz incidente (co-propagación) o en dirección contraria (contra-propagación). Si por el contrario la energía es mayor (mayor frecuencia) se produce la dispersión anti-Stokes (Sembroiz, 2013; Álvarez, Hernández, \& Quiroz, 2007; Hernández, 201 1). La representación del proceso SRS, en cuanto a niveles electrónicos, puede apreciarse en la Figura 1.

La Figura 1 indica que un fotón con energía Wp (señal naranja) es absorbido por el medio y realiza una transición desde el estado fundamental a un estado virtual de energía excitado; tras un tiempo, parte de esa energía es cedida y

a

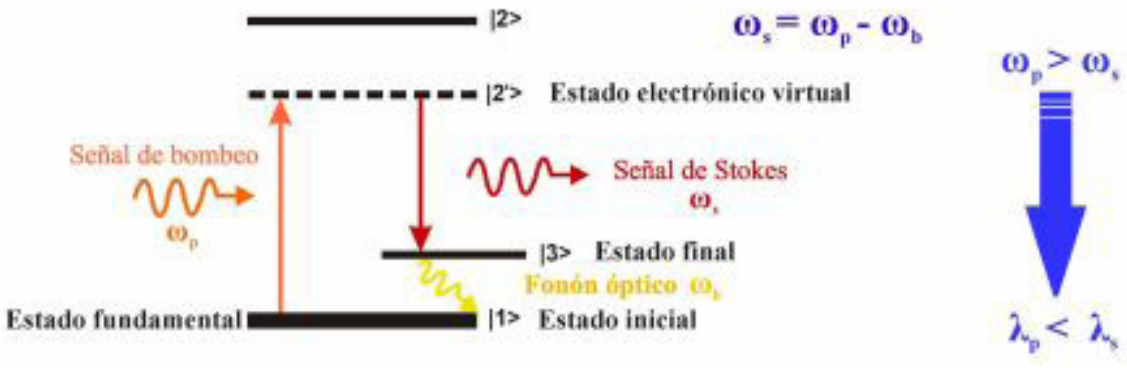




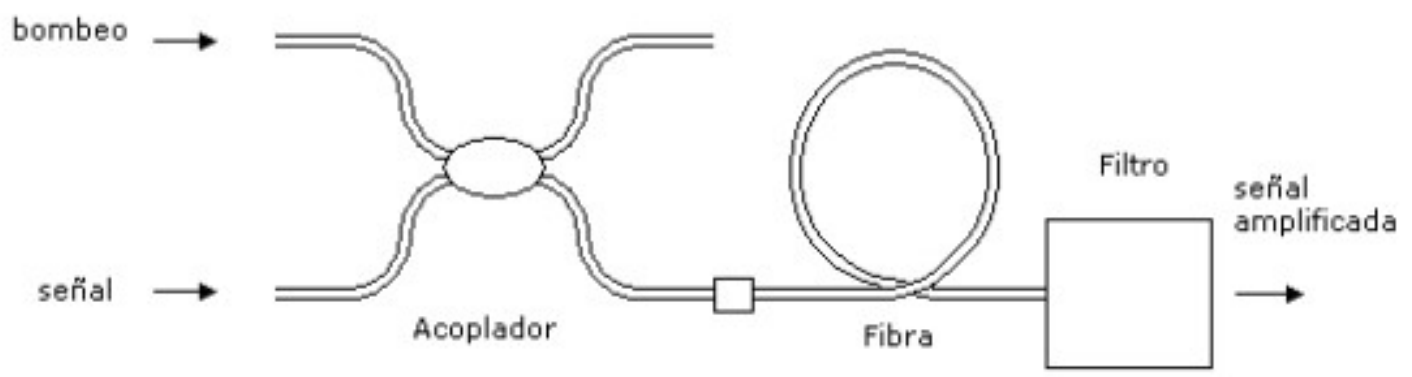

Figure 2. Diagram of a Raman amplifier (Álvarez et al., 2007) / Diagrama de un amplificador Raman (Álvarez et al., 2007)

la restante da origen a un nuevo fotón de energía Ws (señal rojo). Si el estado final de la energía cedida está ubicado un nivel superior que el estado inicial, la emisión del fotón se produce a una menor frecuencia (mayor longitud de onda) que el fotón incidente; en este caso, los fotones emitidos producen la onda de Stokes. Si por el contrario, el estado final de la energía cedida está ubicado un nivel inferior que el estado inicial, la emisión del fotón se produce a una mayor frecuencia (menor longitud de onda) que el fotón incidente; en este caso, la onda que forma los fotones emitidos es una onda anti-Stokes (Hernández, 2011; Carrasco, 2007); como consecuencia de este proceso, el fotón inicial deja de existir, de manera que los amplificadores Raman deben ser bombardeados ópticamente para producir ganancia.

La amplificación Raman usa el SRS como mecanismo de ganancia del amplificador (Rocco el al., 2009). Para conseguir un amplificador Raman utilizando la fibra óptica como medio de ganancia, la señal de bombeo y la señal útil deben trasmitirse en la misma fibra, sin importar la dirección de propagación; produciéndose así, la SRS. La energía se transfiere del bombeo a la señal mediante el proceso Raman, estimulado mientras ambas radiaciones se van propagando por la fibra (Álvarez et al., 2007). La Figura 2 muestra cómo una fibra puede ser usada como amplificador Raman, donde el bombeo y la señal se inyectan en la fibra a través de un acoplador de fibra.

\section{Fibras compensadoras de dispersión}

Para combatir la CD (fenómeno lineal que produce ensanchamiento de los pulsos transmitidos), se han desarrollado las Fibras Compensadoras de Dispersión (DCF, Dispersion Compensating Fiber), las cuales son ampliamente usadas en los modernos enlaces ópticos; su característica principal es presentar una alta dispersión negativa, con valores que oscilan entre -100 y -300 ps/ nm.km (el primero es el de mayor uso comercial), lo que resulta una pendiente negativa para compensar la dispersión positiva de la fibra en las bandas $\mathrm{C}$ y L; tales bandas, funcionan empleando pequeños tramos de fibras de dispersión cromática elevada y de signo contrario a la que ha introducido la fibra principal; de esta manera, se espera que de tramo en tramo, la dispersión cromática total sea prácticamente nula, lo que evita la excesiva deformación de los pulsos de luz y la distorsión de la señal (Hoyos \& Vélez, 2013; Mena \& Mendoza, 2009; Chomycz, 2009). ger wavelength) than the incident photon; in this case, the photons emitted produce the Stokes wave. On the other hand, if the final state of the transferred energy is located at a lower level than the initial state, the photon emission occurs at a higher frequency (shorter wavelength) than the incident photon; in this case, the wave that forms the photons emitted is an anti-Stokes wave (Hernández, 2011; Carrasco, 2007); as a consequence of this process, the initial photon ceases to exist, so Raman amplifiers must be optically bombarded to produce gain.

Raman amplification uses SRS as the amplifier gain mechanism (Rocco et al., 2009). To obtain a Raman amplifier using the optical fiber as a gain medium, the pumping signal and the useful signal must be transmitted on the same fiber, regardless of the direction of propagation; thus, the SRS is produced. The energy is transferred from the pumping to the signal by the Raman process, stimulated while both radiations are propagated on the fiber (Álvarez et al., 2007). Figure 2 shows how a fiber can be used as a Raman amplifier, where pumping and signal are injected into the fiber through a fiber coupler.

\section{Dispersion compensating fibers}

To combat CD (linear phenomenon that produces broadening of transmitted pulses), Dispersion Compensating Fibers [DCF] have been developed, which are widely used in modern optical links; the main characteristic is to present a high negative dispersion, with values ranging from -100 to $-300 \mathrm{ps} / \mathrm{nm} . \mathrm{km}$ (the first one is the one with the highest commercial use), which result in a negative slope to compensate the positive fiber dispersion in the $\mathrm{C}$ and $\mathrm{L}$ bands; such bands operate using small sections of high chromatic dispersion fibers and opposite to the one introduced by the main fiber; in this way, it is expected that the whole chromatic dispersion will be practically null, which avoids the excessive de- 
formation of the light pulses and the distortion of the signal (Hoyos \& Vélez, 2013; Mena \& Mendoza, 2009; Chomycz, 2009).

The most relevant properties of the DCF are attenuation, dispersion coefficient, noise figure and effective area (Hoyos \& Vélez, 2013):

- the attenuation is loss of the power level of the signal, changes linearly with the distance of the link, that is, the greater fiber length, the greater attenuation and vice versa;

- the scattering coefficient is a linear phenomenon that deforms transmitted pulses, if it is excessive, it will manifest in the overlap of $1 \mathrm{~s}$ and $0 \mathrm{~s}$, which generates distortion and errors in decoding; this value is characterized by being negative and being one of the most important parameters, since it allows to counteract the total dispersion accumulated in the link of the conventional fiber;

- the figure of merit defines the relationship between dispersion and DCF attenuation; and

- the effective area is the core section of the fiber through which all light power passes (Gaxiola, 2005).

There are three basic schemes to compensate the GD:

- pre-compensation scheme, where the CD is compensated before the transmission fiber section;

- post-compensation scheme, where the CD is compensated after the fiber; and

- symmetrical compensation scheme, in which DCF sections are used, before and after the transmission fibers.

Figure 3 shows the proposed schemes.

In the development of the present work the post-compensation technique is taken into account in order to reduce the BER (Bit Error Rate) and to witness in a more significantly way the nonlinear effects, due to a lower power level decrease compared to the pre-compensation technique (Hoyos \& Vélez, 2013; Criollo \& Lasso, 2014). Likewise, the impulse that the signal must have to be amplified by Raman requires that there are no connections that generate considerable losses between the transmitter and the optical fiber that will be used as an amplification medium.
Las propiedades más relevantes de la DCF son: la atenuación, el coeficiente de dispersión, la figura de ruido y el área efectiva (Hoyos \& Vélez, 2013):

- la atenuación es pérdida del nivel de potencia de la señal, cambia linealmente con la distancia del enlace, es decir, a mayor longitud de la fibra mayor atenuación y viceversa;

- el coeficiente de dispersión es un fenómeno lineal que deforma los pulsos transmitidos, si es excesivo, se manifestará en la superposición de 1s y 0s, lo cual genera distorsión y errores en decodificación; este valor se caracteriza por ser negativo y por ser uno de los parámetros más importantes, ya que permite contrarrestar la dispersión total acumulada en el enlace de la fibra convencional;

- la figura de merito define la relación que existe entre la dispersión y la atenuación de la DCF; y

- el área efectiva es la sección del núcleo de la fibra por la cual atraviesa toda la potencia lumínica (Gaxiola, 2005).

Existen tres esquemas básicos de compensar la CD:

- esquema pre-compensación, en donde se compensa la CD antes del tramo de la fibra de trasmisión;

- esquema post-compensación, en donde se compensa la CD después de la fibra; y

- esquema de compensación simétrica, en el cual se emplean tramos de DCF, antes y después de las fibras de transmisión.

La Figura 3 plasma los esquemas planteados.
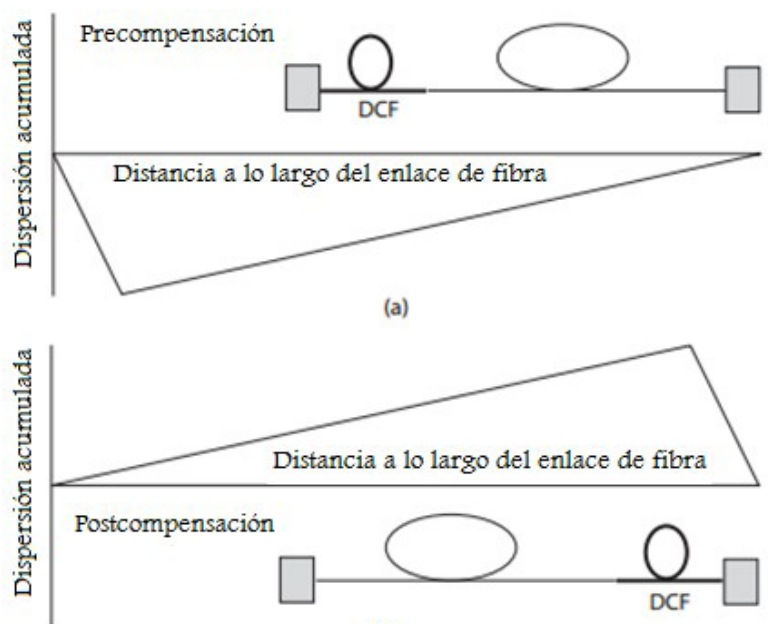

(b)

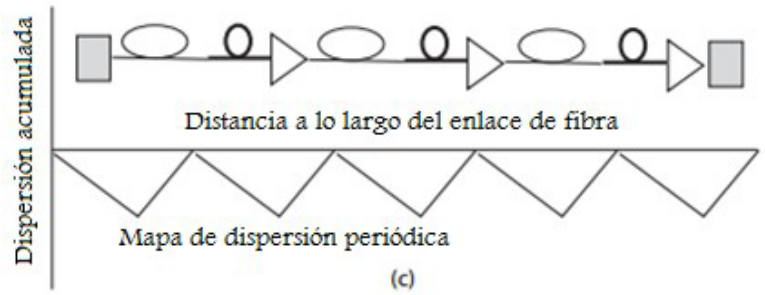

Figure 3. Optical compensation techniques for CD (Agrawal, 2002)/ Técnicas de compensación ópticas para la CD (Agrawal, 2002) 


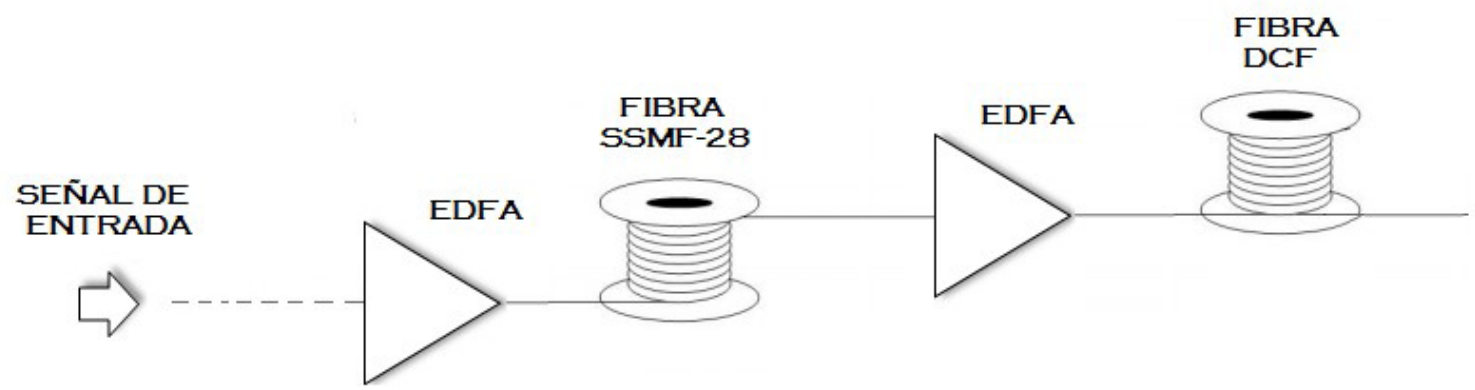

Figure 4. Scheme for a configuration with EDFA amplification without Raman injection (Grüner-Nielsen et al., 2006) / Esquema para una configuración con amplificación EDFA sin inyección Raman (Grüner-Nielsen et al., 2006)

En el desarrollo del presente trabajo se tiene en cuenta la técnica de post-compensación, con el fin de reducir la BER (Bit Error Rate) y presenciar más significativamente los efectos no lineales, debido a un menor decremento del nivel de potencia en comparación con la técnica de pre-compensación (Hoyos \& Vélez, 2013; Criollo \& Lasso, 2014). De igual manera, la impulsión que debe tener la señal para ser amplificada mediante Raman, requiere que no existan empalmes que generen pérdidas considerables entre el transmisor y la fibra óptica que va a ser usada como medio de amplificación.

\section{Configuraciones Raman}

Gruner-Nielsen, Qian y Gaarde (2006) definen las siguientes configuraciones Raman: amplificación EDFA sin inyección Raman, inyección Raman sin amplificación EDFA e inyección Raman con amplificación EDFA.

La configuración tradicional con amplificación EDFA en ausencia de inyección Raman presenta dos etapas de amplificadores EDFA, una fibra DCF y una fibra principal SSMF-28. Se colocan amplificadores tipo EDFA en configuración Booster e Inline para superar la pérdida introducida por la DCF, proceso evidenciado en la Figura 4.

En la configuración en la cual se inyecta Raman a la fibra Se suprimen ambos amplificadores tipo EDFA, lo cual permite la amplificación en cualquier banda y menor costo, ya que la cantidad de dispositivos implementados en la red se reduce. Sin embargo, los amplificadores Raman, al requerir altas potencias de bombeo, adicionan costo significativo al enlace. La luz de bombeo se inyecta, ya sea en la misma

\section{Raman configurations}

Gruner-Nielsen, Qian and Gaarde (2006) define the following Raman configurations: EDFA amplification without Raman injection, Raman injection without EDFA amplification and Raman injection with EDFA amplification..

The traditional configuration with EDFA amplification without Raman injection has two stages of EDFA amplifiers, a DCF fiber and a main fiber SSMF-28. EDFA amplifiers are adjusted in Booster and Inline configuration to overcome the loss introduced by the DCF, a process evidenced in Figure 4.

In the configuration in which Raman is injected into the fiber, both EDFA amplifiers are suppressed which allows amplification in any band and lower cost, since the number of devices implemented in the network is reduced. However, Raman amplifiers due to the requiring of high pumping power, add significant cost to the link. The pumping light is injected either in the same direction (co-propagation) or in the opposite direction (counter-propagation) of the input signal. Figure 5 shows above-mentioned configuration.

Figure 6 shows a configuration in which not only Raman is injected into the SSMF-28 fiber through a high pumping power, generally on the order of watt, but also

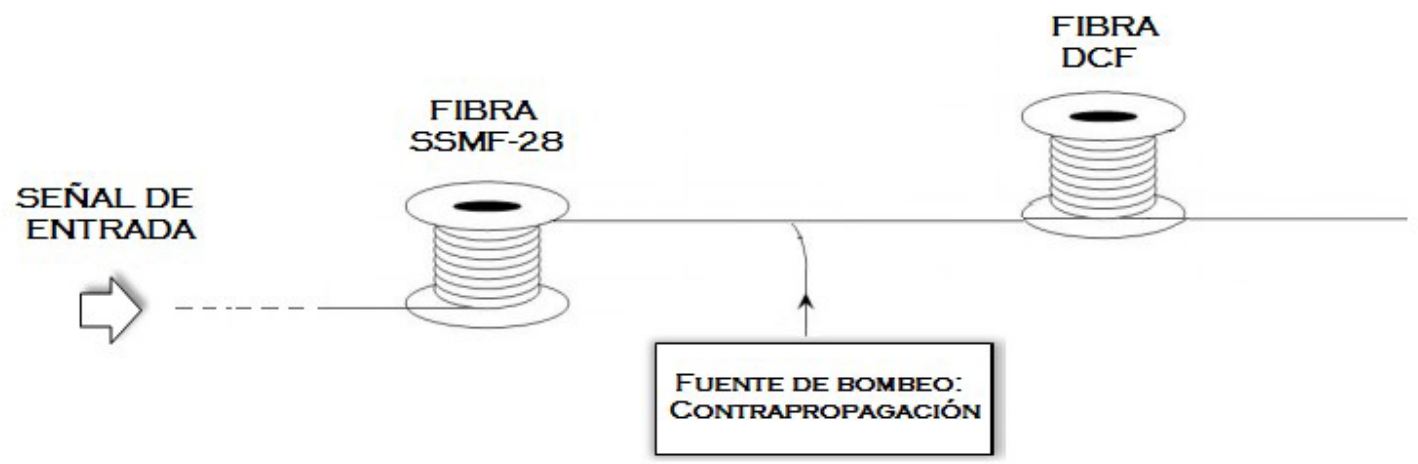

Figure 5. Scheme for a Raman Injection configuration without EDFA amplification (Grüner-Nielsen et al., 2006) / Esquema para una configuración de inyección Raman sin amplificación EDFA (Grüner-Nielsen et al., 2006) 


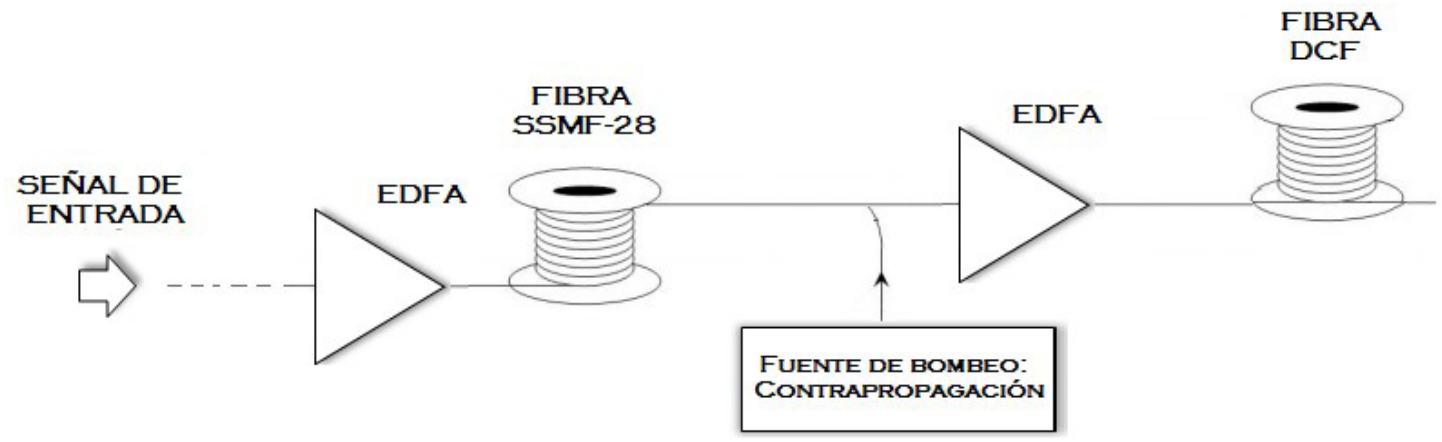

Figure 6. Scheme for a Raman Injection configuration with EDFA amplification (Grüner-Nielsen et al., 2006) / Esquema para una configuración de inyección Raman con amplificación EDFA (Grüner-Nielsen et al., 2006)

an EDFA amplification stage is used. This scheme is called "Hybrid scheme or assisted Raman" and is used in systems of long distances, where the use of DCF is essential.

The pumping required by Raman amplifiers is that of counter-propagation, which is preferred in the design and implementation of distributed Raman amplifier systems (Agrawal, 2002), due to the lower pumping-induced noise coupling on the signal, as well as a less dependence of the gain with the polarization in comparison with the schemes of co-propagation (Neves, Freitas, Almeida, \& Calmon, 2003). In fact, the counter-propagation pumping scheme is often the most used, because the transmission signal is less affected by nonlinear effects such as FWM. This is because the distributed Raman amplifier with counter-propagation configuration amplifies the signals of lower power near the end of the span (Neves \& Calmon, 2005). Also, the counter-propagation scheme provides a high level of output gain, with the consequence of a higher noise, in relation to other pumping configurations (Grüner-Nielsen et al., 2006).

\section{Optical degradations}

Optical degradations are factors that influence unwanted modifications of the original signal, greatly affecting the performance of optical communications systems. Optical degradations are grouped into two categories: linear effects and nonlinear effects, as follows:

- linear effects are optical degradations that do not depend on the transmission, Figure 7 shows the classification of linear effects present in the transmissions on optical fiber;

- nonlinear effects occur mainly due to high power and changes in the refractive index of the medium, with reference to optical intensity and dispersion dirección (co-propagación) o en la dirección contraria (contra-propagación) de la señal de entrada. La Figura 5 ilustra lo expuesto.

En la Figura 6 se muestra una configuración en la cual no solo se inyecta Raman a la fibra SSMF-28 a través de una alta potencia de bombeo, generalmente del orden del vatio, sino también, se utiliza una etapa de amplificación EDFA. Este esquema es denominado "Esquema híbrido o Raman asistido" y es empleado en sistemas de largas distancias, donde se hace indispensable el uso de DCF.

El bombeo requerido por los amplificadores Raman es el de contra-propagación, el preferido en el diseño e implementación de los sistemas de amplificadores Raman distribuidos (Agrawal, 2002), debido al menor acoplamiento de ruido inducido por el bombeo sobre la señal, así como a una menor dependencia de la ganancia con la polarización, en comparación con los esquemas de co-propagación (Neves, Freitas, Almeida, \& Calmon, 2003). De hecho, el esquema de bombeo en contra-propagación es, a menudo, el más usado, porque la señal de transmisión es menos afectada por los efectos no lineales, como FWM. Esto es así porque el amplificador Raman distribuido con configuración de contra-propagación amplifica las señales de menor potencia cerca del final del span (Neves \& Calmon, 2005). Asimismo, el esquema de contra-propagación proporciona un alto nivel de ganancia de salida, con la consecuencia de un mayor ruido, en con respecto de otras configuraciones de bombeo (Grüner-Nielsen et al., 2006).

\section{Degradaciones ópticas}

Las degradaciones ópticas son factores que influencian modificaciones no deseadas de la señal original, afectando considerablemente el desempeño de los sistemas de comunicaciones ópticos. Las degradaciones ópticas se agrupan en dos categorías: efectos lineales y efectos no lineales, como se indica a continuación:

- los efectos lineales son degradaciones ópticas que no dependen de la transmisión, en la Figura 7 se muestra la clasificación de los efectos lineales presentes en las transmisiones sobre fibra óptica;

- los efectos no lineales ocurren principalmente por las altas potencias y los cambios en el índice de refracción 


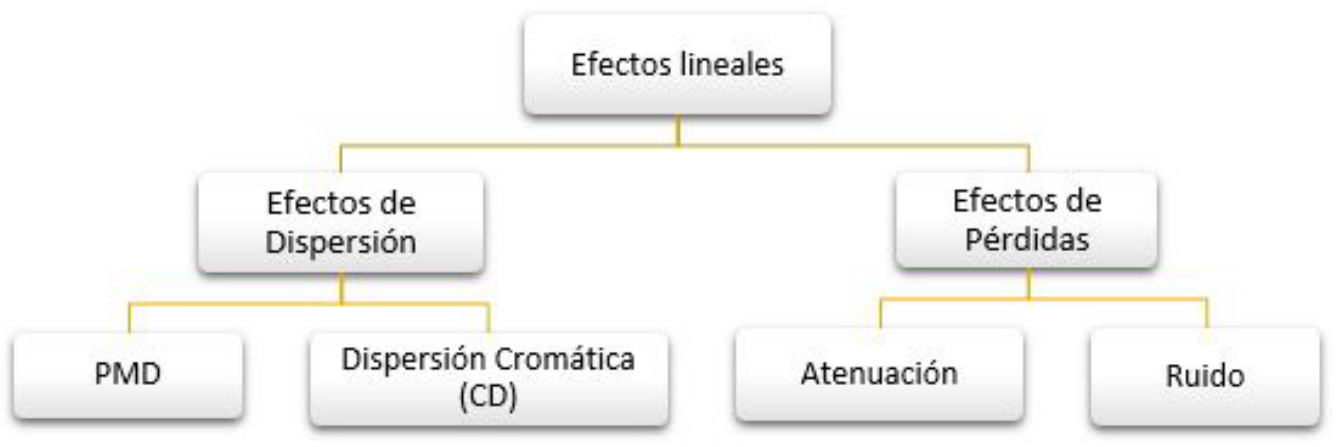

Figure 7. Classification of linear effects / Clasificación de los efectos lineales

del medio, con referencia a la intensidad óptica y a los fenómenos de dispersión (Chan, 2010; Agredo, López, Toledo, \& Ordoñez, 2011). En la Figura 8 se muestra la clasificación de los efectos no lineales presentes en las transmisiones sobre fibra óptica.

En general, los efectos no lineales provocan un deterioro en la calidad de la señal transmitida y obligan a limitar la potencia de transmisión, el número de canales, la distancia del enlace y la tasa de transmisión, entre otros. El impacto que genera cada uno de estos efectos en la señal no tiene la misma influencia (Singh \& Singh, 2007).

\section{Parámetros de monitoreo óptico}

El monitoreo de desempeño óptico [OPM, Optical Perfomance Monitoring] se refiere al monitoreo a nivel físico de la calidad de la señal, para obtener un buen rendimiento de ésta en el dominio óptico (García, 2006). Para el análisis y la evaluación del desempeño de la señal óptica de un enlace de transmisión por fibra óptica, existe una serie de parámetros y técnicas que provee información sobre el desempeño de la red (ITU-T Rec.G.697-2012). Estos parámetros se describen, de manera general, a continuación:

\section{Factor Q}

Se define como la Relación Señal a Ruido Eléctrica [ESNR, Electrical Signal to Noise Ratio] en la entrada de un circuito de decisión de un receptor; tras realizar una comparación de señales eléctricas, dicho circuito permite

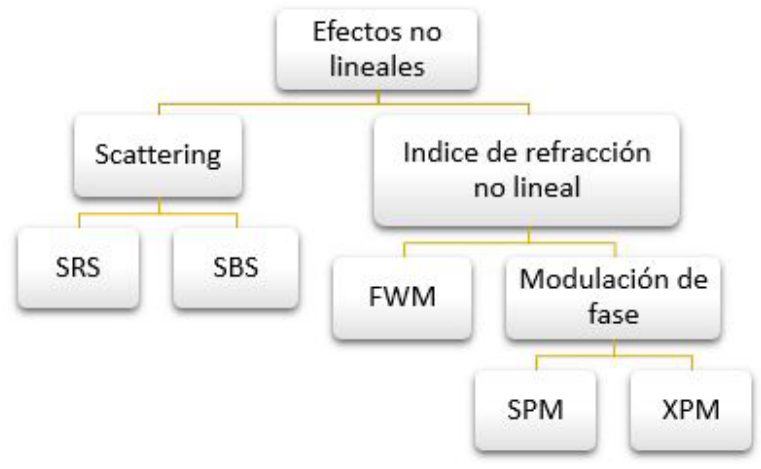

Figure 8. Classification of nonlinear effects / Clasificación de los efectos no lineales phenomena (Chan, 2010; Agredo, López, Toledo, \& Ordoñez, 2011). Figure 8 shows the classification of nonlinear effects present in the transmissions on optical fiber.

In general, nonlinear effects cause deterioration in the quality of the transmitted signal and force to limit transmission power, number of channels, link distance and transmission rate, among others. The impact of each one of these effects on the signal does not have the same influence (Singh \& Singh, 2007).

\section{Optical monitoring parameters}

Optical Performance Monitoring [OPM] refers to the physical level monitoring of signal quality, to obtain a good performance of this one in the optical domain (García, 2006). For the analysis and performance evaluation of the optical signal of an optical fiber transmission link, there are a number of parameters and techniques that provide information about the network performance (ITU-T Rec.G.697-2012). These parameters are generally described as follows:

\section{Q factor}

It is defined as the Electrical Signal to Noise Ratio [ESNR] at the input of a decision circuit of a receiver; after making a comparison of electrical signals, said circuit allows measuring the quality that has had the link to differentiate the "1" from the "0". A higher value of Q means that the logical levels transmitted are more clearly recognized. The $Q$ factor is considered as a qualitative indicator of the real BER, as it measures both the top and the bottom of the "eye" in order to know the quality of the signal (ITU-T-Rec.G .Sup.39, 2012).

\section{Bit Error Rate [BER]}

It is the most important measurement parameter in optical communications for the measurement of system performance; represents the number of bits that have been transmitted 
erroneously with respect to the total transmitted, measured in reception. BER is affected by noise, dispersion and nonlinear effects; such degradations can be counteracted by the use of dispersion compensators, using amplifiers, increasing transmission power and reducing losses, among other parameters and elements that contribute to maintaining a BER target (Hoyos \& Vélez, 2013).

\section{Eye diagram}

It allows the analysis of the waveforms of the pulses that are propagated in the transmission channel, from which it is possible to deduce measurement parameters like the BER and the $Q$ factor. It represents the superposition of the different combinations of ones and zeros in a given time range. In addition, it allows the observation of parameters that determine the quality of the signal, through two types of crosses:

- crossing time, where the opening and closing of the eye occurs; and

- crossing amplitude, which consists of the voltage level that causes the opening and closing of the eye, and is defined in a BIT period (Denmark, 2002; Semiconductor Components Industries, 2014).

\section{Theoretical approaches and re- lated studies}

To date, multiple studies have been made to counteract the limitations of transmission speed and length of the optical links, caused by the attenuation and the different dispersions; in addition, the use of DCFs as an optimal technique to compensate the chromatic dispersion which becomes a degrading alteration of the link. Having said that, it is relevant to have theoretical contributions, coming from advances, research and work related to the topic. In the present study, these are mentioned in their respective chronological order.

Emori, Akasaka, and Namiki (1998) show that the gain is saturated as input power increases, saturation has almost no dependence on the wavelength, which allows us to know an important property of DCF to characterize the network; in addition to this, general system parameters such as channels, typical $\lambda s$ and a specific distance are mentioned. Also, revision of a WDM network is added, using combined polarization for four channels; the losses are analyzed in the presence and absence of DCF, evaluating system performance through the noise figure by varying the wavelength.

Liao and Agrawal (1999) demonstrate that through numerical simulations, using Raman amplification with a bidirectional pumping scheme and performing dispersion com- medir la calidad que ha tenido el enlace, para lograr diferenciar el " 1 " del " 0 ". Un mayor valor de Q significa que se reconoce con más claridad los niveles lógicos transmitidos. El factor $Q$ es considerado como un indicador cualitativo de la BER real, ya que efectúa mediciones, tanto de la parte superior, como de la parte inferior del "ojo" para así conocer la calidad de la señal (ITU-T-Rec.G.Sup.39, 2012).

\section{Tasa de error de Bit [BER]}

Es el parámetro de medida más importante en comunicaciones ópticas para la medición del desempeño del sistema; representa el número de bits que se han transmitido erróneamente respecto del total transmitido, medido en recepción. La BER se ve afectada por el ruido, la dispersión y los efectos no lineales; tales degradaciones pueden contrarrestarse al emplear compensadores de dispersión, empleando amplificadores, incrementando la potencia de transmisión y reduciendo pérdidas, entre otros parámetros y elementos que contribuyen a mantener una BER objetivo (Hoyos \& Vélez, 2013).

\section{Diagrama del ojo}

Permite el análisis de las formas de onda de los pulsos que se propagan en el canal de transmisión, de él se pueden deducir parámetros de medición como la BER y el Factor Q. Representa la superposición de las distintas combinaciones de unos y ceros en un rango de tiempo determinado. Además, permite observar parámetros que determinan la calidad de la señal, a través de dos tipos de cruces:

- cruce de tiempo, donde se produce la apertura y cierre del ojo; y

- cruce de amplitud, el cual consiste en el nivel de voltaje que produce la apertura y cierre del ojo, y se define en un periodo de bit (Dinamarca, 2002; Semiconductor Components Industries, 2014).

\section{Aproximaciones teóricas y estudios relacionados}

Hasta la fecha se han realizado múltiples estudios para contrarrestar las limitaciones de velocidad de transmisión y longitud de los enlaces ópticos, causados por la atenuación y las diferentes dispersiones; además, la utilización de las DCF, como técnica óptima para compensar la dispersión cromática, la cual se convierte en una alteración degradante del enlace. Dicho esto, es relevante contar con aportes teóricos, provenientes de avances, investigaciones y trabajos relacionados con el tema. En el presente estudio, éstos se mencionan en su respectivo orden cronológico.

Emori, Akasaka, y Namiki (1998) demuestran que la ganancia se satura a medida que se incrementa la potencia de entrada, la saturación casi no tiene dependencia de la longitud de onda, lo cual permite conocer una propiedad importante de las DCF para caracterizar la red; adicional a ello, se mencionan parámetros generales del sistema como canales, $\lambda$ s típicas y una distancia puntual. A esto se suma la revisión de una red WDM, usando polarización 
combinada para cuatro canales; las pérdidas son analizadas en presencia y ausencia de DCF, evaluando desempeño del sistema mediante de la figura de ruido variando la longitud de onda.

Liao y Agrawal (1999) demuestran que a través de simulaciones numéricas, al emplear amplificación Raman, utilizando un esquema de bombeo bidireccional y realizando compensación de dispersión, se alcanza una velocidad de 40 Gbps en un solo canal sobre distancias transoceánicas, manteniendo un espacio de $100 \mathrm{~km}$ entre estaciones de bombeo.

Por su parte, Knudsen y Nielsen (2000) indican las propiedades de dispersión típicas para diferentes fibras de dispersión, debido a que los sistemas de transmisión ópticos de ultra alta capacidad y de gestión de dispersión se hacen inevitables; esto, ya que su ausencia de control, limitará significativamente la distancia de transmisión y su correcto funcionamiento. Considerando el efecto de dispersión citad, se hace indispensable mencionar a Peucheret, Tokle, Knudsen, y Rasmuss (2001), quienes desarrollan una simulación WDM para ocho canales, empleando nuevos tipos de fibras compensadoras de dispersión para fibras monomodo estándar, con el fin de evaluar el desempeño frente a efectos no lineales y el cross-channel, verificando la atenuación respecto de variaciones de la distancia; dicho estudio, incorpora referentes conceptuales y teoricos, respecto de los efectos lineales y las fibras compensadoras de dispersión DCF.

En cuanto a los amplificadores se refiere, Pucm, Chbat, Henrie, y Weaver (2001) exponen un esquema de transmisión WDM de larga distancia para la banda S, usando amplificadores compensadores de dispersión Raman, lo cual resultó exitoso; también consideran que los DCRA son una tecnología clave para la expansión fiable y rentable de las redes ópticas en la banda S.

Como referentes concernientes a la DCF, es posible considerar el estudio abordado por Cani, Freitas, Almeida, \& Calmon (2003), quienes plantean y exponen que el sistema SMF-DSF $(100 \mathrm{Km})$ genera demasiado ruido debido a la longitud de la fibra, pero tiene mayor facilidad en su configuración. Mientras tanto, Kimsas, Staubo, Bjornstad, y Slagsvold (2004) analizaron el principio de co-propagación, que consiste en insertar aisladores entre las secciones del amplificador DCF, para así bloquear el efecto de la copia retarda causado por la RBS de la fibra compensadora, logrando así, una considerable reducción de pérdidas en el receptor final.

En concordancia, y de manera amplía, Grüner-Nielsen et al., (2006) argumentan y exponen que mediante las DCF y las configuraciones Raman, la reducción de pérdidas es significativamente importante, lo cual se ve reflejado cuando analizan el estudio de un parámetro trascendental como propiedad para elegir una buena DCF, como lo es la Doble Retrodispersión Rayleigh [DRB] que fue evaluada para cuatro tipos de fibras. Este es un efecto pensation, a speed of 40 Gbps is reached in a single channel over transoceanic distances, maintaining a space of $100 \mathrm{~km}$ between pumping stations.

For their part, Knudsen and Nielsen (2000) indicate typical dispersion properties for different dispersion fibers, because ultra-high capacity optical transmission and dispersion management systems become unavoidable; this, since their absence of control, will limit significantly the distance of transmission and its correct operation. Considering the dispersion effect previously mentioned, it is necessary to reference Peucheret, Tokle, Knudsen, and Rasmuss (2001), who develop a WDM simulation for eight channels, using new types of dispersion compensating fibers for standard single-mode fibers, in order to evaluate the performance against nonlinear effects and the cross-channel, verifying the attenuation with respect to variations in distance; said study, incorporates conceptual and theoretical references regarding linear effects and dispersion compensating fibers.

As far as the amplifiers are concerned, Pucm, Chbat, Henrie, and Weaver (2001) expose a long-distance WDM transmission scheme for the S-band using dispersion compensating Raman amplifiers, which was successful; they also consider that DCRAs are a key technology for reliable and cost-effective expansion of optical networks in the S-band.

As references concerning DCF, it is possible to consider the study addressed by Cani, Freitas, Almeida, \& Calmon (2003), who argue and explain that the SMF-DSF system (100 Km) generates too much noise due to the length of the fiber, but has greater ease in its configuration. Meanwhile, Kimsas, Staubo, Bjornstad, and Slagsvold (2004) analyzed the principle of co-propagation, which consists of inserting insulators between the sections of the DCF amplifier, in order to block the effect of the delayed copy caused by the RBS of the compensating fiber, thus achieving a considerable reduction of losses in the final receiver.

Grüner-Nielsen et al., (2006) argue and explain that the reduction of losses is significantly important through DCF and Raman configurations, which is reflected when analyzing the study of a transcendental parameter as property to choose a good DCF, as is the Double Rayleigh Backscattering [DRB] that was evaluated for four types of fibers. This is an undesirable effect for the optical link, in this way was ratified that when DCF is used in the fibers, a better performance is achieved, whereas without the using of DCF the performance was low; however, the work is focused on finding the most suitable properties to choose an optimized DCF. 
The exploration work made by Saito, Freitas, and Matos (2007) shows that the increase in Raman gain increases the efficiency for short wavelengths, and also compensates the increase in attenuation, for a fiber of $6 \mathrm{Km}$ in the O-band. Complementing such notions, Shtyrina, Turitsyn, Fedoruk, and Sha (2007) show how system performance can be improved by the pre-encoding source; in addition, the statistics for 3 bits are obtained and it is proceed to quantify the strong dependent pattern ISI. Both studies are based on theoretical references and approaches that may be useful to be referenced and incorporated for the development of the objective proposed in this article.

Returning to some precepts mentioned before, Galdámez (2007) develops a work from the types of existing amplifiers; the focus of his project was based on the two most used amplifiers for the design of an optical communication system in DWDM; these are: the Erbium Doped Fibre Amplifier [EDFA] and the Raman amplifier. Additionally, it corroborates the idea that optical amplifiers are elements that compensate losses and attenuation, to achieve greater distances, amplifying only the photon flow; these are used in WDM and DWDM systems. One of the most suitable amplifiers to use is the Raman amplifier, since it provides characteristics that represent advantages over the EDFA. Such characteristics refer to: that the same fiber is converted into an amplifying medium; having a rather flat gain region, whereby all signal lengths are amplified; and to amplify other bands, in addition to C-band. This project contributes in a decisive way for the development of the proposed objective in this article, due to the incorporation of a significant proportion of the concepts addressed to be carried out.

On the other hand, Forzati, Berntson, and $\mathrm{M}^{\mathrm{o}}$ artensson (2008) demonstrate that asynchronous phase modulation increases transmission for the NRZ-OOK system in ultra-long distance WDM systems; in the same line of analysis, we find Alzate and Cárdenas (2011), who highlight advanced modulation formats for the transmission of $40 / 100 \mathrm{~Gb} / \mathrm{s}$, compared to the standard technology of $10 \mathrm{~Gb} / \mathrm{s}$, on optical fiber in short and long distance, as well as some degradations caused by: noise produced by optical amplifiers, chromatic dispersion, PMD and effects of fiber nonlinearities. They also ratify that one of the most widely used options for long-range transmission is Wavelength Division Multiplexing [WDM].

Simultaneously, Orellana (2012) argues that, due to the growing demand for data transport capacity in the metropolitan environment, as a result of the introduction of services and applications with high bandwidth consumption, there indeseable para el enlace óptico, es de este modo, que se revalidó que cuando se utiliza DCF en las fibras, se logra un mejor rendimiento, mientras que sin la DCF el rendimiento era bajo; sin embargo, el trabajo está enfocado en encontrar las propiedades más adecuadas para elegir una DCF optimizada.

El trabajo de exploración, realizado por Saito, de Freitas, y de Matos (2007) muestra que el aumento de la ganancia de Raman incrementa la eficiencia para longitudes de onda cortas, y además compensa el aumento de la atenuación, para una fibra de $6 \mathrm{~km}$ en la banda-O. Complementando tales nociones, Shtyrina, Turitsyn, Fedoruk, y Sha (2007) muestran cómo el rendimiento del sistema se puede mejorar por la fuente de pre-codificación; adicionalmente, se obtienen las estadísticas para 3 bits y se procede a cuantificar el patrón dependiente fuerte ISI. Ambos estudios, parten de referentes teóricos y de aproximaciones que pueden resultar útiles para ser referenciados e incorporados para el desarrollo del objetivo propuesto en el presente artículo.

Retomando algunos preceptos mencionados, Galdámez (2007) desarrolla un trabajo a partir de los tipos de amplificadores existentes; el enfoque de su proyecto se fundamentó en los dos amplificadores más utilizados para el diseño de un sistema de comunicación óptico en DWDM; estos son: el amplificador EDFA [Erbium Doped Fibre Amplifier] y el amplificador Raman. Adicionalmente, corrobora que los amplificadores ópticos son elementos que compensan pérdidas y atenuación, para así alcanzar distancias mayores, amplificando únicamente el flujo de fotones; éstos, son utilizados en sistemas WDM y DWDM. Uno de los más indicados a utilizar, es el amplificador Raman, dado que proporciona características que permiten plantear que poseen ventajas frente a los EDFA. Tales características refieren a: que la misma fibra se convierta en medio amplificador; el poseer una región de ganancia bastante plana, por lo que todas las longitudes de la señal se amplifican; y por amplificar otras bandas, además de la banda C. Dicho proyecto aporta de manera determinante para el desarrollo del objetivo planteado en el presente artículo, por incorporar gran parte de los conceptos abordados para llevarse a cabo.

Por otra parte, Forzati, Berntson, y $\mathrm{M}^{\mathrm{o}}$ artensson (2008) demuestran que la modulación de fase asíncrona aumenta la transmisión para el sistema NRZ-OOK en sistemas WDM de ultra larga distancia; en la misma línea de análisis, encontramos a Alzate y Cárdenas (2011), quienes resaltan formatos de modulación avanzados para la transmisión de 40/100Gb/s, en comparación con la tecnología $10 \mathrm{~Gb} / \mathrm{s}$ estándar, sobre fibra óptica en sistemas de corta y larga distancia, así como algunas degradaciones causadas por: ruido producido por amplificadores ópticos, dispersión cromática, PMD y efectos de no linealidades de la fibra. De igual manera ratifica que una de las opciones más utilizadas para transmisión de largo alcance son los sistemas WDM [Wavelength Division Multiplexing]. 
Simultáneamente, Orellana (2012) argumenta que, debido a la creciente demanda de capacidad de transporte de datos en el entorno metropolitano, producto de la introducción de servicios y aplicaciones con gran consumo de ancho de banda, se ha suscitado gran interés en los sistemas DWDM, los cuales permiten introducir múltiples grupos de servicios y múltiples longitudes de onda por grupo sobre una misma fibra. Algunos ejemplos son la transmisión de 16, 32/40 o 64/80/96 longitudes de onda con Multiplexación por división en el tiempo a 2,5 y $10 \mathrm{Gbit} / \mathrm{s}$.

Por primera vez se empleó las DCF como un medio de ganancia Raman debido a que las DCF tienen altos niveles de dopaje de germanio y áreas efectivas pequeñas, por lo que las ganancias de Raman son bastante altas (Hansen, Veselka, Jacobovitz, \& Gruner, 1998), razón por la cual actualmente los amplificadores Raman integran compensación de dispersión y amplificación Raman. Se realizan múltiples estudios experimentales de dispersión de la fibra estándar y DCF, se integra el uso de DCF en conjunto con diferentes configuraciones de bombeo para evaluar la amplificación Raman (Brueckner, Ji-hong, \& Schuste, 2010).

Benavides (2014) trabaja a partir de un caso específico, en este sentido, caracteriza una red con fibra óptica utilizando tecnología DWDM desde la ciudad de Cotacachi hasta el sector de Apuela (Ecuador); producto de ello, manifiesta que el uso de amplificadores ópticos permite amplificar todas las longitudes de onda, a la vez que incrementa la potencia de la señal después de la multiplexación o antes de la demultiplexación. Además, resalta que el empleo de amplificadores Raman garantiza una mejor distribución de potencia a lo largo de la fibra óptica, y reducen los efectos no lineales; los amplificadores Raman son usados en conjunto con amplificación EDFA para cubrir un margen de longitudes de onda más amplios no cubierto por los EDFA.

Rojas (2015) profundiza sobre la modulación por división de longitud de onda y la modulación por división de onda densa; reitera que DWDM limita la velocidad binaria, debido al efecto lineal dispersión por el modo de polarización (PMD), reacción originada por la utilización de varias longitudes de onda, producto de distorsiones no lineales a causa del desplazamiento y la dispersión de la fibra óptica.

Bonilla (2017), en su estudio del amplificador híbrido EDFA-RAMAN en las bandas C Y L, muestra las diferentes combinaciones de amplificadores ópticos empleados hoy en día. Los amplificadores Raman se usan típicamente en configuración co-propagación, donde el bombeo introducido a la fibra óptica se realiza en dirección opuesta a las señales DWDM; por lo tanto, se asegura que la mayor parte de la amplificación se produce al final de la trayectoria de la fibra, donde los niveles de señal son más bajos, evitando que el nivel de potencia al comienzo de cada etapa de amplificación supere el umbral de efectos no lineales; funcionan, tanto en la banda $\mathrm{C}$, como en la banda $\mathrm{L}$ (Lara \& Reis, 2010), pero debido a su baja ganancia en has been great interest in DWDM systems, which allow introducing multiple groups of services and multiple wavelengths per group on the same fiber. Some examples are the transmission of $16,32 / 40$ or $64 / 80 / 96$ wavelengths with time division multiplexing at 2,5 and $10 \mathrm{Gbit} / \mathrm{s}$.

For the first time DCF was used as a Raman gain medium because DCFs have high levels of germanium doping and small effective areas, so Raman gains are quite high (Hansen, Veselka, Jacobovitz, \& Gruner, 1998), which is why Raman amplifiers currently integrate dispersion compensating and Raman amplification. Several experimental studies of dispersion of the standard fiber and DCF are carried out, integrating the use of DCF in conjunction with different pumping configurations to evaluate the Raman amplification (Brueckner, Ji-hong, \& Schuste, 2010).

Benavides (2014) works from a specific case, in this sense, characterizes an optical fiber network using DWDM technology from the city of Cotacachi to the sector of Apuela (Ecuador); as a result, he states that the use of optical amplifiers allows amplification of all wavelengths, while increasing signal strength after multiplexing or before demultiplexing. In addition, he emphasizes that the use of Raman amplifiers guarantees a better distribution of power along the optical fiber, and reduce nonlinear effects; Raman amplifiers are used together with EDFA amplification to cover a wider range of wavelengths not covered by the EDFAs.

Rojas (2015) delves into wavelength division modulation and dense wave division modulation; he reiterates that DWDM limits the binary speed, due to the linear effect by polarization mode dispersion (PMD), reaction originated by the use of several wavelengths, product of nonlinear distortions due to the displacement and dispersion of the optical fiber.

Bonilla (2017), in his study of the hybrid EDFA-RAMAN amplifier in $\mathrm{C}$ and $\mathrm{L}$ bands, shows the different combinations of optical amplifiers used nowadays. Raman amplifiers are typically used in co-propagation configuration where the pumping introduced to the optical fiber is performed in the opposite direction to the DWDM signals; therefore, it is ensured that most of the amplification occurs at the end of the fiber path, where signal levels are lower, preventing that the power level at the beginning of each amplification exceed the threshold of nonlinear effects; they operate in both C-band and L-band (Lara \& Reis, 2010), but because of their low gain in C-band, the- 
se amplifiers are commonly used in L-band. One disadvantage to consider when using Raman-EDFA amplifiers is the need for several pumping wavelengths to generate a high flat gain (Bonilla, 2017; Iturri, 2014).

On the other hand, as the number of pumping lasers increases, the waving decreases significantly, although the overall system gain increases by $5 \mathrm{~dB}$ for each laser. It is recalled that the use of many pumping lasers is not efficient, but this can be mitigated to a certain extent by increasing the number of channels, using a Raman-EDFA configuration (Martini, Castellani, Pontes, Ribeiro, \& Kalinowski, 2009; Martini, Castellani, Pontes, Ribeiro, \& Kalinowski, 2009; y Bonilla, 2017).

\section{Conclusions}

The bibliographical review shows the multiple experiments and works performed using Raman amplification for transmission in large distance links using DWDM systems.

The increase in transmission power greatly influences the appearance of linear and nonlinear effects that degrade to a great extent the performance of the network, which is why, employing Raman amplifiers, ensures a better distribution of power and, simultaneously, compensates for dispersion and attenuation along the optical fiber.

Due to the great need for data transmission, it was necessary to replace WDM systems with DWDM systems, which allow multiplexing $\mathrm{N}$ number of channels or wavelengths by a single optical medium; currently transmit at speeds of up to $40 \mathrm{Gbps}$.

DWDM networks are characterized, as well as the outstanding performance of DCFs to compensate for chromatic dispersion and, in conjunction with Raman amplifiers, to amplify all wavelengths, thus guaranteeing a better power distribution along the optical fiber.

Raman amplification is very useful because amplifies the signal in a greater number of bands, compared to the traditional EDFA amplifiers; however, precaution should be taken with the power level required by the pumping source, since a considerable increase, increments the general level of intensity, which leads to a greater influence of nonlinear effects that degrade the performance of the network. SK la banda $\mathrm{C}$, estos amplificadores se usan comúnmente en banda L. Un inconveniente a tener en cuenta al emplear amplificadores Raman-EDFA es la necesidad de varias longitudes de onda de bombeo para generar una ganancia alta y plana (Bonilla, 2017; Iturri, 2014).

Por otro lado, al aumentar el número de láseres de bombeo, la ondulación disminuye significativamente, aunque la ganancia global del sistema aumenta $5 \mathrm{~dB}$ para cada láser. Se recuerda que el uso de muchos láseres de bombeo no es eficiente, pero esto se puede mitigar en cierta medida, aumentando el número de canales, usando una configuración Raman-EDFA (Martini, Castellani, Pontes, Ribeiro, \& Kalinowski, 2009; Martini, Castellani, Pontes, Ribeiro, \& Kalinowski, 2009; y Bonilla, 2017).

\section{IX. conclusiones}

Mediante la revisión bibliográfica se puede evidenciar los múltiples experimentos y trabajos realizados empleando amplificación Raman para transmisión en enlaces de gran distancia empleando sistemas DWDM.

El incremento de la potencia de transmisión incide considerablemente en la aparición de efectos lineales y no lineales que degradan en gran medida el desempeño de la red, razón por la cual, emplear amplificadores Raman garantiza una mejor distribución de la potencia y, al mismo tiempo, compensa la dispersión y la atenuación a lo largo de la fibra óptica.

Debido a la gran necesidad de transmisión de datos, fue necesario reemplazar los sistemas WDM por sistemas DWDM, que permiten multiplexar $\mathrm{N}$ número de canales o longitudes de onda por un solo medio óptico; actualmente, transmiten a velocidades superiores a $40 \mathrm{Gbps}$.

Se caracterizan redes DWDM, de igual manera, se resalta el relevante desempeño de las DCF para compensar la dispersión cromática y, en conjunto con los amplificadores Raman, amplificar todas las longitudes de onda, garantizando así, una mejor distribución de potencia a lo largo de la fibra óptica.

La amplificación Raman es de gran utilidad, porque amplifica la señal en un mayor número de bandas, a comparación de los amplificadores tradicionales EDFA; no obstante, se debe tener precaución con el nivel de potencia requerido por la fuente de bombeo, puesto que elevar considerablemente, incrementa el nivel general de intensidad, lo que da lugar a una mayor influencia de efectos no lineales que degradan el desempeño de la red. $\mathbf{S} T$ 


\section{References / Referencias}

Agrawal, G. (2002). Fiber-optic communication systems. New York, NY: Wiley.

Agredo , J., López, J., Toledo, A., \& Ordoñez, H. (2011). Efectos no lineales y su relación con los parámetros de transmisión de una red WDM. Revista Facultad de Ingeniería, UPTC, 20(31), 23-35.

Alvarado, O. (2009). Recomendaciones para el diseño, implementación y puesta en servicio de red DWDM para empresa de telecomunicaciones en el Salvador [thesis]. Universidad Don Bosco: San Salvador, El salvador.

Álvarez, E., Hernández, C., \& Quiroz, G. (2007). Transmisiones ópticas mediante el uso de solitones [thesis]. Instituto Politenico Nacional: México.

Alzate, D. \& Cardenas, A. (2011). Retos en la transmisión de 40/100Gb/s sobre fibra óptica. Revista en Telecomunicaciones e Informática, 1(2), 23-60.

Benavides, A. (2014). Diseño de una red con fibra óptica utilizando tecnología DWDM desde la ciudad de Acotachi hasta el sector de Apuela [thesis]. Universidad Técnica del Norte: Ibarra, Ecuador.

Bonilla, J. (2017). Survey of hybrid EDFA/RAMAN in C and L bands. Revista Ingeniería, Matemáticas y Ciencias de la Información, 4(7), 13-24.

Brueckner, V., Ji-hong, L., \& Schuste, A. (2010). Optical amplification and dispersion compensation in one step. Journal of $X_{i}$ 'an University of posts and telecommunicat ions, 15(5), 14-18.

Cani, S., Freitas, M, Almeida, R., \& Calmon, L. (2003). Raman amplifier performance of dispersion compensating fibers. IEEE Microwave and Optoelectronics Conference IMOC. Proceedings of the SBMO/IEEE MTT-S International, 2. IEEE.

Carrasco, A. (2007). Generación de frecuencias de referencia para la calibración de sistemas WDM en comunicaciones ópticas [thesis]. Universidad de Granada: España.

Chan, C. C. (2010). Optical Perfomance Monitoring, Advanced Techniques for Next-Generation Photonic Networks. Amsterdam, The Netherlands: Elseiver.

Chomycz, B. (2009). Planning fiber optic networks. New York, NY: McGraw-Hill.

Criollo, S. \& Lasso, F. (2014). Impacto de la fibra óptica sobre el desempeño de una red WDM a 10 Gbps [thesis]. Universidad del Cauca: Popayán, Colombia.

Dinamarca, J. (2002). Análisis de diagramas de ojo [thesis]. Universidad Técnica Federico Santa María Valparaiso, Chile.

Emori, Y., Akasaka, Y., \& Namiki, S. (1998). Broadband lossless DCF using Raman amplification pumped by multichannel WDM laser diodes. IEEE Electronics Letters, 34(22), 2145-2146.

Ferrin, J. (2014). Estudio y diseño de una propuesta para el mejoramiento de la capacidad de la red de fibra óptica de la UCSG utilizando tecnología DWDM. Universidad Catòlica de Santiago de Guayaquil: Ecuador.

Forzati, M., Berntson, A., Mårtensson, J., Pincemin, E., \& Gavignet, P. (2008, May). NRZ-OOK Transmission of $16 \times 40$ Gb/s over 2800 km SSMF Using Asynchronous Phase Modulation. In Conference on Lasers and Electro-Optics (p. CThAA3). Optical Society of America.

Galdámez, M. (2007). Criterios de selección para los amplificadores EDFA y Raman tipo 'óptico-óptico' en DWDM. Universidad de San Carlos, Ciudad de Guatemala.

García, C. (2006). Análisis de la tecnología IP sobre WDM [thesis]. Universidad Austral: Valdivia, Chile.

García, A. (2011). Diseño y caracterización de sistemas optoelectrónicos de comunicaciones basados en fibra óptica [thesis]. Universidad Carlos II de Madríd: España.

Gaxiola, O. (2005). Simulador de un sistema de comunicación óptico empleando multicananlizador por división de longitudes de onda (WDM) [thesis] Instituto Politécnico Nacional: Tijuana, Mexico.

Gruner-Nielsen, L., Qian , Y., \& Gaarde, P. B. (2006). Dispersion compensating fibers for Raman applications. In Raman Amplifiers for Telecommunications 1 (pp. 115-143). New York, NY: Springer.

Hansen, P. B., Jacobovitz-Veselka, G., Gruner-Nielsen, L., \& Stentz, A. J. (1998). Raman amplification for loss compensation in dispersion compensating fibre modules. Electronics letters, 34(11), 1136-1137.

Hernández, J. (2011). Theory and experiment in modular Raman spectroscopy with fiber optics applied to the analysis of pigments [thesis]. Barcelona, España: Universitat Politécnica de Catalunya.

Hoyos H, K., \& Vélez G, J. (2013). Impacto de las propiedades de una fibra compensadora de dispersión (DCF) en el diseño de un sistema WDM [thesis]. Popayán, Colombia: Universidad del Cauca.

Iturri, I. (2014). Diseño y caracterización de nuevas topologías de redes de sensores multiplexados en longitud de onda mediante láseres de fibra con emisión multilínea [thesis]. Pamplona, España: Universidad Pública de Navarra.

ITU-T Rec.G.Sup.39. International Telecommunications Union - Standardization Sector [UIT-T]. (2012). Optical system design and engineering considerations. Geneve, Switzerland: ITU

ITU-T Rec. G.694.1. International Telecommunications Union - Standardization Sector [UIT-T]. (2012). Spectral grids for WDM applications: DWDM frequency grid. Geneve, Switzerland: ITU.

ITU-T Rec. G.697. International Telecommunications Union - Standardization Sector [UIT-T]. (2012). Supervisión óptica para sistemas de multiplexación por división en longitud de onda densa. Geneve, Switzerland: ITU

Kimsas, A., Staubo, P., Bjornstad, S., \& Slagsvold, B. (2004). A dispersion compensating Raman amplifier with reduced double rayleigh backscattering, employing standard DCF. IEEE Transparent Optical Networks, Proceedings of 6th International Conference on. Wroclaw, Poland. 
Knudsen, S. \& Nielsen, L. (2000). New fibers for future telecommunication systems. IEEE Lasers and Electro-Optics Society Annual Meeting. LEOS 13th Annual Meeting, 1. Rio Grande.

Lara A, I. \& Reis A, R. (2010). Proposta de prácticas laboratoriais com os equipamentos DWDM do laboratório óptico Optix [thesis]. Brasilia, Brasil: Universidad de Brasilia.

Liao, Z., \& Agrawal, G. (July de 1999). High-bit-rate soliton transmission using distributed amplification and dispersion management. IEEE Photonics Technology Letters, 11, 818-820.

Liu, X. (2002). Optimization of broadband Raman amplification in ultra-long-haul DWDM transmissions. IEEE Lasers and Electro-Optics, 1, 479-480.

Martini, M., Castellani, C., Pontes, M., Ribeiro, M., \& Kalinowski, H. (2009). Multi-pump optimization for Raman+EDFA hybrid amplifiers under pump residual recycling. International Optoelectronics Conference, (pp. 117-121). Belém, Brazil. IEEE.

Melendez, L. (2013). Estudio de intregacíon de redes DWDM con las redes metro ethernet. Univeresidad de Costa Rica: San Pedro, Costa Rica.

Mena S, E. \& Mendoza P, R. (2009). Diseño de una red WDM para Andinatel S. A en la provincia de Tungurahua [thesis]. Quito, Ecuador: Escuela Politécnica Nacional.

Neves, S. \& Calmon, L. C. (2005). Perfomance evaluation of simultaneous dispersion compensation and Raman amplification using microstructured optical fibers. Microwave and Optoelectronics, 2005 SBMO/IEEE MTT-S International Conference, 546-549. IEEE.

Neves, S., Freitas, M., Almeida, R., \& Calmon, L. C. (2003). Raman amplifier perfomance of dispersion compensating fibers. Microwave and Optoelectronics Conference, 2003. IMOC 2003. Proceedings of the 2003 SBMO/IEEE MTT-S International, 2, 553-558. IEEE.

Nuñez, R. (2004). IP-DWDM red óptica metropolitana [thesis]. Cartagena, Colombia: Universidad Tecnológica de Bolívar.

Orellana L, C. (2012). Expansión de una red SDH con tecnología DWDM [thesis]. Ciudad de Guatemala: Universidad de San Carlos.

Peucheret, C., Tokle, T., Knudsen, S., \& Rasmuss, C. (2001). System perfomance of new types of dispersion compensating fibres. IEEE Lasers and Electro-Optics. CLEO '01. Technical Digest. Summaries of papers presented at the Conference. Baltimore.

Pucm, A., Chbat, M., Henrie, J., \& Weaver, N. (2001). Long-haul DWDM NRZ transmission at 10.7Gb/s in S-band using cascade of lumped Raman amplifiers. IEEE Optical Fiber Communication Conferencia y Exposición de OFC, 4. Anaheim, CA. IEEE.

Rocco, M., Rocha, A. M., Neto, B., Correia, C., Segatto, M. V., Pontes, M. J., . . André, P. S. (2009). Brillouin effects in distributed Raman amplifiers under saturated conditions. Microwave and Optoelectronics Conference (IMOC), 2009 SBMO/ IEEE MTT-S International, 841-845. IEEE.

Rojas, L. (2015). Estudio del comportamiento de las redes sónicas de alta velocidad. Revista Tecnocientífica URU, 8, 91-99.

Saito, L., de Freitas, L., \& de Matos, C. (2007). Measurement of Raman gain efficiency in a DCF and its application in optical amplification for the O-band. IEEE Microwave and Optoelectronics Conference. IMOC. SBMO/IEEE MTT-S International. Brazil. IEEE.

Sembroiz A, D. (2013). Desarrollo de un algoritmo energy-aware de enrutamiento y asignación de longitudes de onda en redes ópticas [thesis]. Barcelona, España: Universitat Politècnica de Catalunya.

Semiconductor Components Industries. (2014). Understanding data eye diagram methodology for analyzing high speed digital signals [Publication Order No. 9075/D] . Retrieved from: HYPERLINK "https://wenku.baidu.com/view/ a4177974453610661ed9f495.html?re=view" https://wenku.baidu.com/view/a4177974453610661ed9f495.html?re=view

Shtyrina, O., Turitsyn, S., Fedoruk, M., \& Sha, A. (2007). Patterning effects in WDM RZ-DBPSK SMF/DCF optical transmission at $40 \mathrm{Gbit} / \mathrm{s}$ channel rate. IEEE Lasers and Electro-Optics, and the International Quantum Electronics Conference. CLEOEIQEC. European Conference. Munich. IEEE.

Singh, S. P. \& Singh, N. (2007). Nonlineal effect in optical fibers: Origin management and applications. Progress In Electromagnetics Research, 73, 249-275. 


\section{CURRICULUM VITAE}

Geovanny Andrés Muñoz Castro. Engineer in electronics and telecommunications from Universidad del Cauca (Popayán, Colombia) and student of Master in Electronics and Telecommunications in the same entity. $\mathrm{He}$ worked, as a support engineer, at EMTEL Popayán, a telecommunications enterprise / Ingeniero en Electrónica y Telecomunicaciones de la Universidad del Cauca (Popayán, Colombia) y estudiante de la Maestría en Electrónica y Telecomunicaciones de la misma universidad. Laboró para la empresa de telecomunicaciones EMTEL Popayán, donde desempeño funciones como ingeniero de soporte y apoyo. 